\title{
Blood copper as an indicator of copper status with a note on serum proteins and leucocyte counts in copper-deficient rats*
}

\author{
By I. E. DREOSTI AND G. V. QUICKE \\ Department of Biochemistry, University of Natal, \\ Pietermaritzburg, Republic of South Africa \\ (Received I9 August I966-Accepted 25 September 1967)

\begin{abstract}
I. Albumin, $\alpha_{1^{-}}, \alpha_{2^{-}}, \beta$ - and $\gamma$-globulin fractions were demonstrated in serum from control and copper-depleted rats, but no quantitative difference was found in the distribution of the proteins between the two groups of animals. Both the total number of leucocytes and the number of polymorphonuclear leucocytes increased during copper depletion.

2. Plasma copper content was found to be superior to whole blood copper content as an index of the copper status of rats at intermediate stages of depletion. The copper content of erythrocytes was found to be unaffected even in the severely depleted animals; this explains, in part, the poor response of whole blood copper content to intermediate stages of depletion.

3. A single dose of orally administered copper was reflected in the plasma copper content of depleted rats about $\mathrm{i} 2 \mathrm{~h}$ after dosing. No similar rise was observed in control animals, and the extent of the response was not increased by increasing the dose of copper.

4. It is suggested that plasma copper response to a single oral dose of copper sulphate may provide a useful method for the detection of subnormal copper status in individual farm animals without the necessity of determining breed norms.
\end{abstract}

As described in a previous communication (Dreosti \& Quicke, 1966), adult female rats may be rapidly depleted of copper by feeding with a low-copper diet during pregnancy and lactation. An investigation of hair, liver and blood copper, and of haemoglobin levels, revealed that liver copper analyses, using samples from whole liver homogenates, provided the best index of copper status. Whole blood copper reflected an initial decline in copper status and fell dramatically after the liver reserves had been depleted, but did not parallel intermediate stages of depletion.

Although liver copper levels are widely used for the diagnosis of copper deficiency in animals (Underwood, 1962), the present authors found the copper content of samples taken from different parts of rat or cattle livers to vary by as much as $100 \%$ (unpublished results). Analysis of biopsy samples is therefore unlikely to provide a sufficiently sensitive technique for the diagnosis of a marginal copper deficiency. Furthermore, farmers generally are reluctant to subject high-producing animals to biopsy examination, so that liver analysis does not hold much promise for the investigation, under field conditions, of the copper status of farm animals which do not already show clear-cut signs of deficiency. These considerations prompted a reexamination of blood as the tissue of choice for the clinical evaluation of copper status.

* The findings presented in this paper are taken from a thesis submitted by one of us (I. E. D.) in partial fulfilment of the requirements for the degree of $\mathrm{PhD}$ in the Department of Biochemistry, University of Natal, 1965. 
In the present investigation leucocyte and plasma protein changes were studied in severely copper-deficient female rats, whereas plasma and erythrocyte copper levels were recorded during progressive depletion. In addition, attention was paid to the response of plasma copper levels following an oral dose of an aqueous solution of copper sulphate. Plasma copper content was found to provide a sensitive index of the copper status in rats, and copper administered by mouth was shown to be reflected in the plasma copper concentration of partially depleted animals approximately $12 \mathrm{~h}$ after dosing.

\section{EXPERIMENTAL AND RESULTS}

\section{Reagents}

All chemicals used were of analytical reagent grade, and water was distilled and deionized through an Elgastat multibed ion-exchange resin.

\section{Animals and diets}

Adult female rats of the Wistar strain were used throughout the investigation, and were housed in perspex cages. The copper-deficient diet $(0 . \mathrm{I}-0.25 \mathrm{ppm} \mathrm{Cu})$ consisted of whole milk powder supplemented with $30 \mathrm{ppm}$ manganese as $\mathrm{MnSO}_{4} \cdot 4 \mathrm{H}_{2} \mathrm{O}$ and $40 \mathrm{ppm}$ iron as $\mathrm{FeC}_{6} \mathrm{H}_{5} \mathrm{O}_{7} \cdot \mathrm{H}_{2} \mathrm{O}$ (ferric citrate) (Dreosti \& Quicke, I966). The various procedures used for copper depletion are described on p. 3 .

\section{Sampling techniques and analytical procedures}

Blood samples for serum protein studies were collected by heart puncture from test animals which had been starved for $18 \mathrm{~h}$ before sampling in order to reduce plasma turbidity due to lipaemia (Deutsch \& Goodloe, I945). Serum proteins were separated by starch gel electrophoresis ( $9 \mathrm{~mA}, \mathrm{x} 20 \mathrm{~V}$ for $6 \mathrm{~h}$ ) as described by Smithies (1955, 1959), and quantitative evaluation of the peaks was performed on a modified paper electrophoretogram scanner (Evans Electroselenium Ltd).

Leucocyte counts were carried out on blood samples taken from the tip of the tail, and all animais were handled with equal care to avoid changes in leucocyte levels associated with emotional stress (Farris \& Griffith, 1963). Total and differential counts were made in the manner described by Boddie (1950) and the leucocytes were grouped into lymphocytes and polymorphonuclear leucocytes which were almost entirely neutrophils.

Copper was assayed by a slightly modified sodium diethyl dithiocarbamate method as described in an earlier communication (Dreosti \& Quicke, I966), on blood samples collected by heart puncture and treated with 125 i.u. heparin per I $\mathrm{ml}$ blood to prevent clotting. Before analysis, corpuscles were separated from the plasma by centrifugation at $1000 \mathrm{~g}$ for $30 \mathrm{~min}$ in graduated tubes and the volume of the pellet was taken as an estimate of the packed cell volume.

Liver samples were taken from homogenates prepared from the entire organ by mincing in an agate pestle and mortar. Copper was determined on $\mathrm{I} g$ samples as pre- 
viously described, and moisture was determined by drying to constant weight $(24 \mathrm{~h})$ at $105^{\circ}$.

Severe copper depletion was induced by maintaining freshly mated female rats on the copper-deficient diet throughout pregnancy and the ensuing 3 weeks of lactation. Control animals were treated in the same way but received $25 \mathrm{ppm}$ copper as $\mathrm{CuSO}_{4} \cdot{ }_{5} \mathrm{H}_{2} \mathrm{O}$ in their diet. Liver copper levels of the control and the severely depleted animals ranged respectively from 16.5 to $19 . \mathrm{I}$ and from $\mathrm{I} \cdot 9$ to $2.5 \mathrm{ppm} \mathrm{Cu}$ (dry weight).

\section{Serum proteins and leucocyte counts}

Albumin, $\alpha_{1^{-}}, \alpha_{2^{-}}, \beta$ - and $\gamma$-globulin fractions were demonstrated in the serum from two control and two copper-depleted rats, but no quantitative differences in the distribution of the proteins could be demonstrated.

The mean total and mean differential leucocyte counts for five control and five copper-depleted rats are presented in Table I, from which it can be seen that both the total number of leucocytes and the proportion of polymorphonuclear leucocytes rose significantly $(P=0.05)$ in the depleted animals.

\section{Table 1. Total and differential leucocyte counts in control and copper-deficient rats}

\begin{tabular}{|c|c|c|c|c|}
\hline \multirow[b]{3}{*}{ Treatment } & \multicolumn{2}{|c|}{ (Mean values with their standard errors) } & \multirow{2}{*}{\multicolumn{2}{|c|}{ Differential count }} \\
\hline & & & & \\
\hline & $\begin{array}{l}\text { No. of } \\
\text { rats }\end{array}$ & $\begin{array}{c}\text { (cells } / \mathrm{mm}^{3} \\
\text { blood) }\end{array}$ & $\begin{array}{l}\text { Polymorphs } \\
(\%)\end{array}$ & $\begin{array}{c}\text { Lymphocytes } \\
(\%)\end{array}$ \\
\hline Control & 5 & $10860 \pm 844$ & $3^{6} \pm x \cdot 3$ & $64 \pm x \cdot 7$ \\
\hline Severe $\mathrm{Cu}$ deficiency & 5 & $14440 \pm 780$ & $4 I \pm I \cdot 4$ & $59 \pm 1 \cdot 7$ \\
\hline
\end{tabular}

Packed cell volume and concentrations of copper in plasma and erythrocytes during progressive copper depletion

In order to obtain rats in various stages of depletion, three groups of three lactating dams were maintained on the copper-deficient diet for periods of 1,2 and 3 weeks respectively. A fourth group, of three non-lactating females, was maintained on the copper-deficient diet supplemented with $25 \mathrm{ppm} \mathrm{Cu}$ (dry weight) for 3 weeks before killing for tissue analysis. The values obtained for this group were taken as 'normal' values. The blood was analysed for plasma and erythrocyte copper, and the packed cell volume was also noted. Liver copper was also determined and was taken as an index of the degree of depletion achieved. The results are presented in Table 2 and in Fig. 1, which also includes values for whole blood copper obtained by direct analysis in an earlier but similar experiment (Dreosti \& Quicke, I966).

\section{Response of plasma copper to the oral administration of copper sulphate}

Blood samples $(\mathrm{I} \cdot 5 \mathrm{ml})$ were taken from two control rats and two rats that had been depleted of copper during 5 days of lactation. The animals were dosed by mouth with O. I mg copper as $\mathrm{CuSO}_{4} \cdot{ }_{5} \mathrm{H}_{2} \mathrm{O}$ in I ml water, and further blood samples were taken after 6,12 and $3^{6} \mathrm{~h}$. In a second experiment blood samples were taken from another 
Table 2. Plasma and erythrocyte copper content in lactating rats during progressive copper depletion

\begin{tabular}{|c|c|c|c|c|}
\hline \multirow{3}{*}{$\begin{array}{l}\text { Period } \\
\text { on Cu- } \\
\text { deficient } \\
\text { diet } \\
\text { (weeks) }\end{array}$} & \multicolumn{4}{|c|}{ (Mean values for three rats; range given in parentheses) } \\
\hline & \multicolumn{3}{|c|}{ Copper content of tissues } & \multirow{2}{*}{$\begin{array}{c}\text { Packed } \\
\text { cell } \\
\text { volume } \\
(\%)\end{array}$} \\
\hline & $\begin{array}{c}\text { Liver } \\
\text { (ppm, dry wt) }\end{array}$ & $\begin{array}{l}\text { Plasma } \\
(\mu \mathrm{g} / \mathrm{ml})\end{array}$ & $\begin{array}{l}\text { Erythrocytes } \\
\qquad(\mu \mathrm{g} / \mathrm{ml})\end{array}$ & \\
\hline $0^{*}$ & $\begin{array}{c}18 \cdot 1 \\
(16 \cdot 5-19 \cdot 1)\end{array}$ & $\begin{array}{c}2 \cdot 9 \\
(2 \cdot 6-3 \cdot 2)\end{array}$ & $\begin{array}{c}x \cdot 8 \\
(I \cdot 4-2 \cdot r)\end{array}$ & $\begin{array}{c}4 I \cdot 7 \\
(40 \cdot 8-42 \cdot 8)\end{array}$ \\
\hline $\mathbf{I}$ & $\begin{array}{c}10.8 \\
(8 \cdot 9-12 \cdot 2)\end{array}$ & $\begin{array}{c}I \cdot 3 \\
(0.9 I-I \cdot 8)\end{array}$ & $\begin{array}{c}x \cdot 6 \\
(x \cdot I-I \cdot 8)\end{array}$ & $\begin{array}{c}45 \cdot 0 \\
(44 \cdot 3-45 \cdot 5)\end{array}$ \\
\hline 2 & $\begin{array}{c}6 \cdot 1 \\
(4 \cdot 8-7 \cdot 5)\end{array}$ & $\begin{array}{c}0.82 \\
(0.50-1 \cdot 2)\end{array}$ & $\begin{array}{c}I \cdot 9 \\
(I \cdot 6-2 \cdot I)\end{array}$ & $\begin{array}{c}43^{\cdot 8} \\
\left(43^{\cdot 0-44 \cdot 5)}\right.\end{array}$ \\
\hline 3 & $\begin{array}{c}4 \cdot 0 \\
(3 \cdot 1-5 \cdot 2)\end{array}$ & $\begin{array}{c}0.46 \\
(0.20-0.63)\end{array}$ & $\begin{array}{c}I \cdot 5 \\
(I \cdot 4-I \cdot 7)\end{array}$ & $\begin{array}{c}32 \cdot 3 \\
(30 \cdot 8-34 \cdot 0)\end{array}$ \\
\hline
\end{tabular}

* These rats were not nursing and received the $\mathrm{Cu}$-deficient diet $+25 \mathrm{ppm} \mathrm{Cu}$ for 3 weeks before sampling.

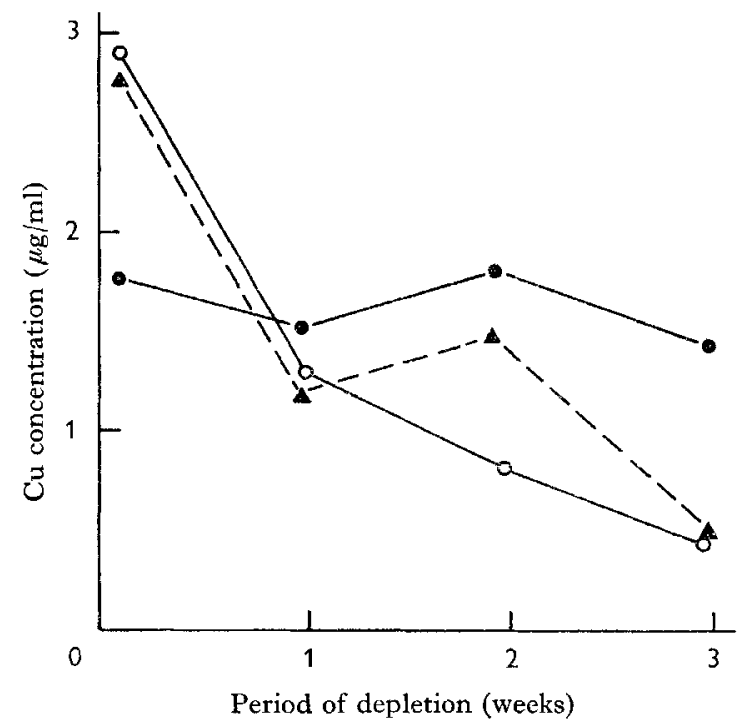

Fig. I. Plasma, erythrocyte and whole blood copper levels in rats during progressive $\mathrm{Cu}$ depletion. $\mathrm{O}-\mathrm{O}$, plasma $\mathrm{Cu} ; \mathbf{-}-$, erythrocyte $\mathrm{Cu} ; \boldsymbol{\Delta}-\boldsymbol{\Delta}$, whole blood $\mathrm{Cu}$ determined by direct assay in a previous investigation (Dreosti \& Quicke, 1966).

two control rats and another two partly depleted animals immediately before, and $\mathrm{I} 2 \mathrm{~h}$ after dosing. Animals were killed immediately after withdrawal of the last blood sample and the concentration of copper in their livers was determined. The results are presented in Table 3 . 
Table 3. Response of plasma copper concentration to a single oral dose of $0 \cdot 1 \mathrm{mg}$ copper sulphate in aqueous solution

(Partial depletion was induced by giving the $\mathrm{Cu}$-deficient diet to nursing dams for 5 days before dosing. Normal Cu status was measured on rats that were not nursing and had received the $\mathrm{Cu}$-deficient diet supplemented with $25 \mathrm{ppm} \mathrm{Cu}$ for 3 weeks before dosing)

\begin{tabular}{|c|c|c|c|c|c|c|c|}
\hline \multirow{2}{*}{$\begin{array}{l}\text { Rat } \\
\text { no. }\end{array}$} & \multirow{2}{*}{$\begin{array}{c}\mathrm{Cu} \\
\text { status }\end{array}$} & \multirow{2}{*}{$\begin{array}{c}\text { Liver } \\
\text { Cu* } \\
\text { (ppm, } \\
\text { dry wt) }\end{array}$} & \multicolumn{5}{|c|}{ Plasma $\mathrm{Cu}(\mu \mathrm{g} / \mathrm{ml})$, at different times after dosing } \\
\hline & & & of $h$ & $6 \mathrm{~h}$ & $12 \mathrm{~h}$ & $24 \mathrm{~h}$ & $36 \mathrm{~h}$ \\
\hline I) & \multirow{5}{*}{ Normal } & 17 & $2 \cdot 4$ & $2 \cdot 3$ & $2 \cdot 8$ & $2 \cdot 6$ & $2 \cdot 5$ \\
\hline 2 & & 20 & $2 \cdot 8$ & $2 \cdot 3$ & $2 \cdot 8$ & $2 \cdot 3$ & $2 \cdot 7$ \\
\hline 3 & & 18 & $2 \cdot 1$ & - & $I \cdot 9$ & - & - \\
\hline 4 & & 30 & 2.5 & - & $3 \cdot 0$ & - & - \\
\hline Mean) & & $(21 \cdot 2$ & $2 \cdot 45$ & $2 \cdot 3$ & $2 \cdot 62$ & $2 \cdot 45$ & $2 \cdot 6$ \\
\hline 5) & \multirow{5}{*}{ Partly depleted } & 12 & $\mathrm{I} \cdot 5$ & $I \cdot 3$ & $2 \cdot 9$ & $2 \cdot 4$ & 0.7 \\
\hline 6 & & 14 & $I \cdot 0$ & 0.7 & $2 \cdot 6$ & $I \cdot 7$ & $I \cdot 2$ \\
\hline 7 & & 14 & $\mathrm{I} \cdot 5$ & - & $2 \cdot 3$ & - & - \\
\hline 8 & & 12 & $1 \cdot 2$ & - & $2 \cdot 9$ & $\longrightarrow$ & - \\
\hline Mean & & $x_{3}$ & $1 \cdot 30$ & $I \cdot O$ & $2 \cdot 72$ & 0.95 & - \\
\hline
\end{tabular}

\section{DISCUSSION}

Serum proteins and leucocyte counts

The occurrence of $\alpha_{1}$ - and $\alpha_{2}$-globulin confirms the findings of $\mathrm{Li}$ (1944) and Espinosa (1961) who have reported that, contrary to the findings of Moore, Levin \& Leathem (1944), $\alpha$-globulin occurs naturally in the serum of normal rats. The results indicate, however, that in the rat serum proteins are not markedly influenced by copper deficiency, which is in contrast to findings with cattle, in which serum $\beta$ globulin and $\gamma$-globulin levels are reported to rise and fall respectively during stages of copper depletion (Coulson, Davies \& Evans, 1960). On the other hand, the total leucocyte count and the number of polymorphonuclear leucocytes rose significantly during depletion in rats, a response not unlike that described in cattle (van Rensburg, I96I). However, the non-specific nature of the response precludes its effective use for the detection of copper depletion in either species.

\section{Copper concentration in plasma and erythrocytes during progressive copper depletion}

In a previous communication (Dreosti \& Quicke, I966) the copper concentration of whole blood was shown to be relatively insensitive to intermediate stages of copper depletion in rats, but the ready availability of blood samples for clinical investigation prompted a more detailed study of the behaviour of blood copper during progressive depletion. In the present investigation, plasma copper levels in lactating dams depleted for 3 weeks were observed to fall to about $16 \%$ of the level found in nonpregnant, non-lactating females fed on a copper-supplemented diet.

Depletion was most rapid during the ist week, but there was no tendency for 
plasma copper levels to stabilize during the 2nd week of depletion, as occurred with whole blood (Dreosti \& Quicke, 1966). The results are similar to those obtained by Dempsey, Cartwright $\&$ Wintrobe (1958) with serum from young rats that had been deprived of adequate dietary copper after weaning.

Erythrocyte copper concentration remained fairly constant throughout the experimental period, but the packed cell volumes decreased by about $23 \%$ after the 2 nd week of depletion. Thus it appears that the tendency for whole blood copper to remain relatively unchanged during the 2 nd week of the depletion is due to the stability of the erythrocyte fraction, whereas the subsequent fall in whole blood copper is due to the reduced contribution of the erythrocytes in addition to the further depletion of plasma copper.

Comparison of the values for plasma and liver copper concentrations show the former to be at least as sensitive an index of copper status as the latter. In fact the drop in copper levels was sharper in plasma than that in liver, the reduction after 3 weeks of depletion amounting respectively to 84.2 and $77.8 \%$, relative to 'normal' levels.

These results obtained with the rat add support to Underwood's (1962) conclusion, based on changes in the copper content of blood during pregnancy in human subjects and on the observations of Wintrobe, Cartwright \& Gubler (1953) on pigs, that 'plasma copper is a more reliable indicator of changes in copper status of an animal than whole blood'.

The usefulness of plasma copper concentration as sole criterion for the detection of subnormal copper status in farm animals is, however, by no means established. The results reported here were obtained under ideal laboratory conditions in which normal animals showed little individual variation. By contrast, van der Grift (1955) recorded large variations, among control animals, in the serum copper levels of cattle, and he concluded that the evaluation of slightly reduced serum copper levels is extremely difficult. The authors were therefore prompted to seek an alternative approach and attention was directed to the measurement of the response of plasma copper concentration to an oral dose of copper sulphate.

\section{Response of plasma copper concentration to the oral administration of copper sulphate}

The sensitivity of plasma copper concentration to copper status has already been noted. At the same time the copper-carrying capacity of plasma does not appear to increase in depleted animals, whereas in the normal dog, serum copper levels are increased only after massive doses of orally administered copper (Gubler, Lahey, Cartwright $\&$ Wintrobe, 1953). Thus it appears that the plasma copper levels in the normal animal represent the saturated transport level, and that increased levels are not easily obtained by an increased dietary intake. If these deductions are correct it may be expected that subnormal plasma copper levels may respond to an oral dose of copper but no such response would be observed in the normal animal with plasma copper already at the saturated level.

In the present investigation oral administration of copper was found to be reflected in an increase in the plasma copper concentration in partly depleted rats approximately $\mathrm{I} 2 \mathrm{~h}$ after dosing, but only a very slight response, or no response, was recorded 
in the control animals. Further tests on the effect of larger doses of copper indicated that amounts of up to $0.8 \mathrm{mg}$ copper had no effect upon the plasma levels of the control rats. In contrast, in partly depleted animals plasma copper levels were found to increase 2- to $2 \frac{1}{2}$-fold $\mathrm{I} 2 \mathrm{~h}$ after dosing with $\mathrm{O} \cdot \mathrm{I} \mathrm{mg}$ copper, although they did not rise above that level after administration of 0.3 or $0.8 \mathrm{mg}$ copper.

It appears therefore that the response of the plasma copper concentration to a single dose of orally administered copper can provide a useful method for the detection of subnormal copper status in a particular individual without the need for extensive determinations of species or breed norms and the natural variation between individuals within the group. It is hoped that these findings with rats will pave the way for the development of a more effective method for the detection of marginal copper depletion in larger animals.

The authors are indebted to Miss M. A. Abbott for her technical assistance, especially in carrying out the total and differential leucocyte counts.

\section{REFERENCES}

Boddie, G. F. (r950). Diagnostic Methods in Veterinary Medicine, 3rd ed. London: Oliver and Boyd Ltd. Coulson, C. B., Davies, P. J. \& Evans, W. C. (1960). F. comp. Path. 70, r99.

Dempsey, H., Cartwright, G. E. \& Wintrobe, M. M. (1958). Proc. Soc. exp. Biol. Med. 98, 520.

Deutsch H. F. \& Goodloe, M. B. (1945). F. biol. Chem. 16r, I.

Dreosti, I. E. \& Quicke, G. V. (1966). S. Afr. F. agric. Sci. 9, $36_{5}$.

Espinosa, E. (1961). Biochim. biophys. Acta 48, 445 .

Farris, E. J. \& Griffith, J. Q. (I963). The Rat in Laboratory Investigation, and ed. New York: Hafner Publishing Co.

Gubler, C. J., Lahey, M. E., Cartwright, G. E. \& Wintrobe, M. M. (I953). F. clin. Invest. 32, 405.

Li, C. H. (1944). F. Am. chem. Soc. 66, 1795.

Moore, D. H., Levin, L. \& Leathem, J. H. (I944). F. biol. Chem. 153, 349.

Smithies, O. (1955). Biochem. F. 61, 629.

Smithies, O. (1959). Biochem. F. 71, 585.

Underwood, E. J. (1962). Trace Elements in Human and Animal Nutrition, and ed. New York: Academic Press Inc.

van der Grift, J. (1955). The Copper Content in Liver and Blood Serum of Fresian Cattle. Verslagen van I andbouwkundige Ondersoekingen, No.6r.ro: Rykslandbouwproefstation, Hoorn, Holland. van Rensburg, S. W. J. (Ig6r). Fmg S. Afr. 36, no. 12, p. 50.

Wintrobe, M. M., Cartwright, G. E. \& Gubler, C. J. (1953). F. Nutr. 50, 395. 